Baseline

\title{
Heavy metals in surface sediments of the intertidal Laizhou Bay, Bohai Sea, China: Distributions, sources and contamination assessment
}

\author{
Jinfeng Zhang a,b,c, Xuelu Gao ${ }^{\text {a,* }}$ \\ ${ }^{a}$ Key Laboratory of Coastal Environmental Processes and Ecological Remediation, Yantai Institute of Coastal Zone Research, Chinese Academy of Sciences, Yantai, Shandong \\ 264003, China \\ ${ }^{\mathrm{b}}$ College of Chemistry and Materials Science, Ludong University, Yantai, Shandong 264001, China \\ ${ }^{\mathrm{c}}$ University of Chinese Academy of Sciences, Beijing 100049, China
}

\section{A R T I C L E I N F O}

\section{Article history:}

Received 24 March 2015

Revised 9 June 2015

Accepted 16 June 2015

Available online 22 June 2015

\section{Keywords:}

Trace elements

Environmental assessment

Marine sediments

Coastal zone

Intertidal environment

Tidal flat

\begin{abstract}
A B S T R A C T
Surface sediments from the intertidal zone of the southwestern Laizhou Bay were analyzed for heavy metals to seek their concentrations, distributions, pollution status, potential ecological risks and possible sources. The concentrations of $\mathrm{As}, \mathrm{Cd}, \mathrm{Cr}, \mathrm{Cu}, \mathrm{Hg}, \mathrm{Ni}, \mathrm{Pb}$ and $\mathrm{Zn}$ were in the ranges of 4.65-9.65, 0.11-0.28, $25.85-42.75,7.57-21.29,0.022-0.054,12.85-25.35,9.65-17.65$ and $38.22-73.81 \mu \mathrm{g} \mathrm{g}^{-1}$ dry sediment weight, respectively. $\mathrm{Cd}$ and $\mathrm{Hg}$ presented a status of no pollution to moderate pollution and moderate to considerable potential ecological risks; they were enriched to some extent at some sampling stations, while the other studied metals were not. The combined effects of the studied metals in the sediments made them have a $21 \%$ probability of being toxic to biota. The results indicated that $\mathrm{As}, \mathrm{Cr}, \mathrm{Cu}, \mathrm{Zn}, \mathrm{Ni}$ and $\mathrm{Pb}$ were mainly from natural contribution, while a significant portion of $\mathrm{Cd}$ and $\mathrm{Hg}$ was likely from anthropogenic discharges in addition to natural inputs.
\end{abstract}

(c) 2015 Elsevier Ltd. All rights reserved.
It is well-known that heavy metals are toxic when their concentrations are over certain thresholds, and have received worldwide concern due to their significant adverse impact on both environment and human health. They are resistant to biodegradation and have the potential for bioaccumulation and biomagnification, which make them pose potential long-term risks for human health and ecosystem. Sediments are not only the effective sink for heavy metals in marine and coastal ecosystems, but also act as a source of metals for aquatic organisms (Chapman et al., 1998; Breslin and Sañudo-Wilhelmy, 1999; Dural et al., 2007; Li and Gao, 2014). Many studies have shown that heavy metals in sediments could significantly impact the health of aquatic ecosystem (Snodgrass et al., 2008; Zheng et al., 2008; Besser et al., 2009). It is therefore important to monitor heavy metals in sediments for the purpose of assessing environmental health risks and developing pollution control strategies and approaches to environmental quality management in a coastal area (Long et al., 1995; SEPA, 2002). With the rapid socio-economic development, the marine ecosystem of China has been facing severe environmental problems such as pollution especially in recent two decades, and the environmental

* Corresponding author at: Key Laboratory of Coastal Environmental Processes and Ecological Remediation, Yantai Institute of Coastal Zone Research, Chinese Academy of Sciences, 17 Chunhui Rd., Yantai, Shandong 264003, China.

E-mail address: xlgao@yic.ac.cn (X. Gao). conditions and ecological risks of heavy metals in sediments of different marine areas attract lots of researchers to study (e.g. Feng et al., 2011; Pan and Wang, 2011; Gao and Chen, 2012; Gao and Li, 2012; Yuan et al., 2012; Gao et al., 2013, 2014, 2015a,b; Yu et al., 2013; Li et al., 2014; Wu et al., 2014).

The intertidal zones are complex and dynamic aquatic environment, where physical, chemical, and biological interactions between continents and marine systems have profound influence on the transport and fate of heavy metals (Lau and Chu, 2000; Spencer, 2002). Therefore intertidal sediment is identified as one of the major reservoirs of heavy metals from both natural and anthropogenic sources, and it also plays an important role in the biogeochemical cycling of metals (Duran et al., 2008; Ding et al., 2009). Compared with that of other marine areas, the distribution of heavy metals in estuaries and their surrounding tidal areas is generally affected more by various influences of intense human activities, riverine and atmospheric inputs, coastal and seafloor erosions, and biological activities.

The Laizhou Bay is one of the three major bays of the Bohai Sea, making up $\sim 10 \%$ of its total area. There are almost ten rivers flowing into the Laizhou Bay from its southwestern coast, most of which are small and seasonal. Around the Bay, industrialization and urbanization are booming in the past decades. Due to the abundant seawater and underground brine resources, hundreds of chemical enterprises are established along the southwestern 
coast of the Laizhou Bay. Although previous studies showed that heavy metal pollution on the whole could not be a key threat to the ecological system of the Laizhou Bay, some evidence indicated that the concentrations and potential mobility of some heavy metals in the surface sediments from some spots in the lowermost reaches of the rivers in the southwestern coast of the Bay may have negative influence on biota (Zhuang and Gao, 2013, 2014a,b; Gao et al., 2015b). Yet, no information can be found about the heavy metals in the intertidal sediments of this area, so the condition remains unknown up to now. In order to have more information about the environmental conditions of heavy metals in this area, an investigation was carried out in the intertidal zone of this area. The main objectives of this study were: (1) to determine the concentrations of heavy metals including $\mathrm{As}, \mathrm{Cd}, \mathrm{Cr}, \mathrm{Cu}, \mathrm{Hg}, \mathrm{Ni}, \mathrm{Pb}$ and $\mathrm{Zn}$ in the surface sediments of the intertidal zone in the southwestern Laizhou Bay (SWLZB); (2) to evaluate the pollution status and identify the possible sources of these metals; and (3) to assess their potential ecological risks.

The sediment samples used in this study were collected from 18 stations in the intertidal zone of the SWLZB during 17-24 July, 2013. Fifteen sampling stations were arranged along the bank of the major estuaries of this area extending from the high tide mark to the low tide mark and formed five transects. Sites A1 to A3, B1 to $\mathrm{B} 3, \mathrm{C} 1$ to $\mathrm{C} 3, \mathrm{E} 1$ to $\mathrm{E} 3$ and $\mathrm{F} 1$ to $\mathrm{F} 3$ were in the tidal flats off the Xiaoqinghe River mouth, Bailanghe River mouth, Yuhe River mouth, Weihe River mouth and Jiaolaihe River mouth; stations D1 to D3 were located at a non-estuarine tidal flat area (Fig. 1). At each transect, three sampling stations were arranged landwards at the areas near to the low tide mark, the middle tide mark and the high tide mark. All materials that were utilized for sampling, treatment and storage were carefully chosen and properly treated to minimize external anthropogenic contamination of the samples. At each sampling station, the top $0-5 \mathrm{~cm}$ sediment was collected with a plastic spatula and packed in a new polyethylene zipper bag, and a total of 18 samples were obtained. After the collection, the samples were stored and transported to the laboratory in a cooler box with ice packs and transferred to a $\sim 4{ }^{\circ} \mathrm{C}$ fridge for further analyses.

Freeze-dried aliquots were ground and homogenized using an agate mortar and pestle. Then, $\sim 0.05 \mathrm{~g}$ of each sample was digested in closed Teflon digestion vessel with $8 \mathrm{ml}$ mixed acid solution $\left(\mathrm{HNO}_{3}: \mathrm{HClO}_{4}: \mathrm{HF}=2: 1: 5\right)$, the mixture was heated in an electric heating thermostat at $170^{\circ} \mathrm{C}$ for $48 \mathrm{~h}$ and then unclosed and heated on an electric heating plate at $100^{\circ} \mathrm{C}$ until it evaporated to semi-dryness. After cooling, the digested samples were brought to a final volume of $40 \mathrm{ml}$ using a solution of $2 \%$ nitric acid. The concentration of $\mathrm{Al}$ was determined by inductively coupled plasma optical emission spectrometry (PerkinElmer Optima 7000 DV) for the purpose of calculating enrichment factors of each element. Heavy metals $(\mathrm{Cr}, \mathrm{Cd}, \mathrm{Cu}, \mathrm{Ni}, \mathrm{Pb}$ and $\mathrm{Zn})$ were measured with inductively coupled plasma mass spectrometry (PerkinElmer Elan DRC II). As and $\mathrm{Hg}$ were measured by hydride generation atomic fluorescence spectrometry (Beijing Haiguang Instrument Co. AFS-2202).

The granularity of each sample was measured with a Malvern Mastersizer 2000 laser diffractometer to calculate the percentages

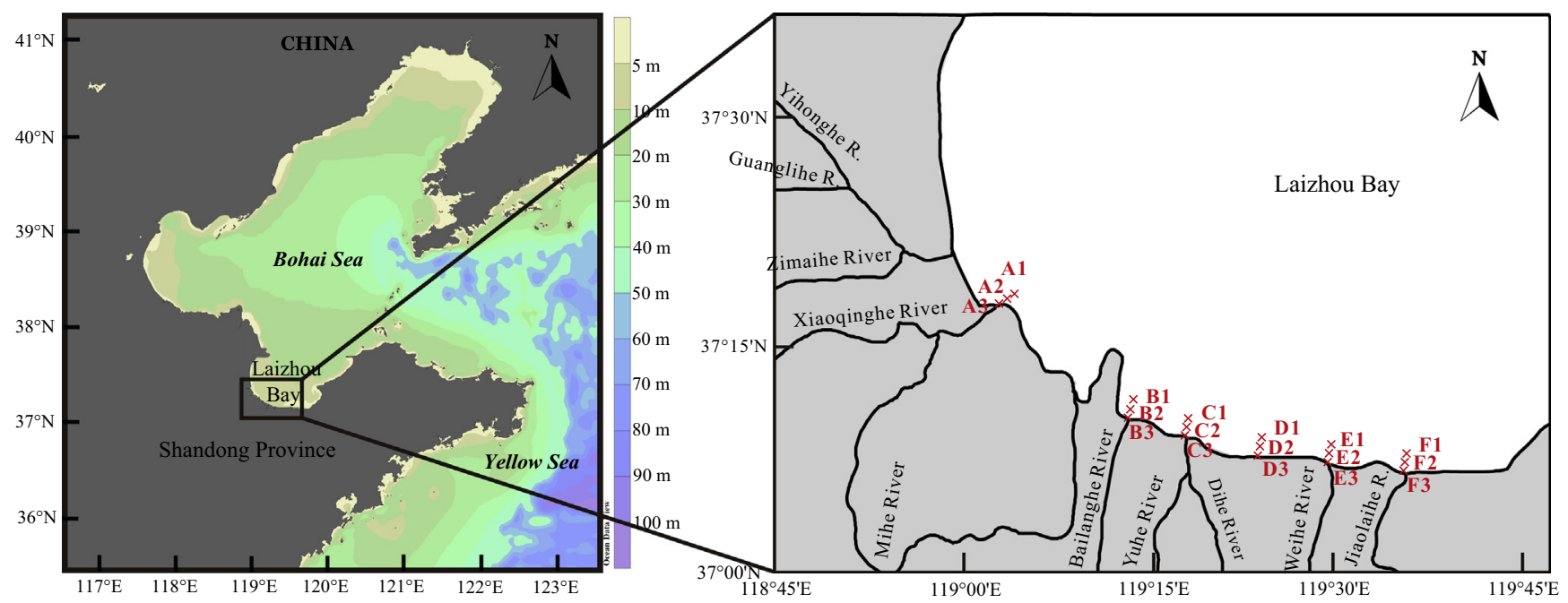

Fig. 1. Location of sampling stations in the intertidal zone of the SWLZB.
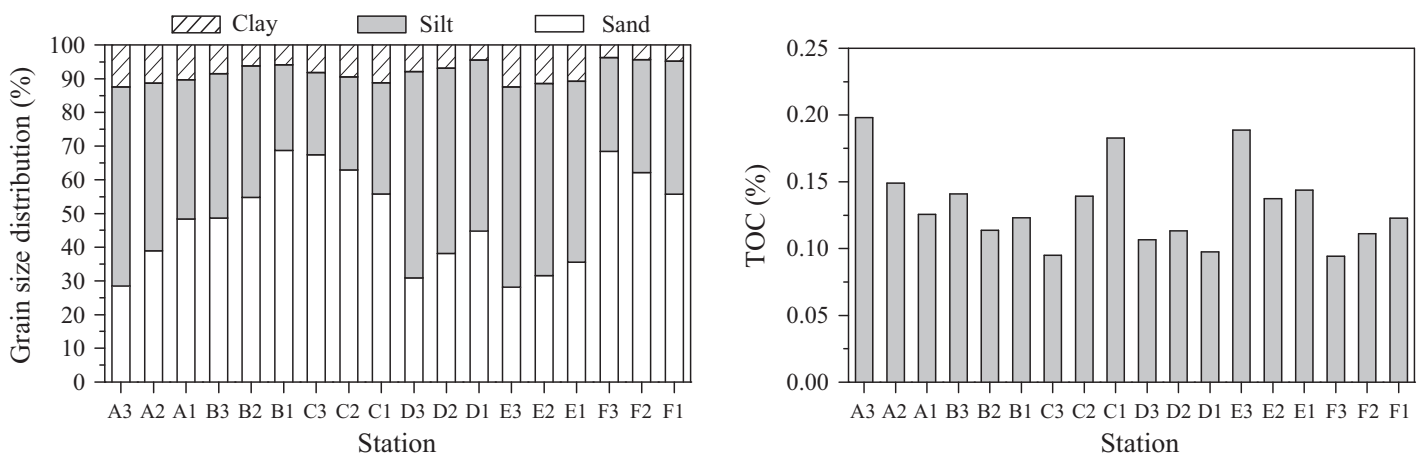

Fig. 2. Grain size (left) and TOC (right) distributions in the surface intertidal sediments of the SWLZB. 


\section{Table 1}

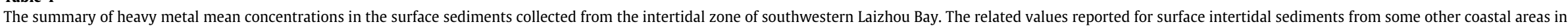

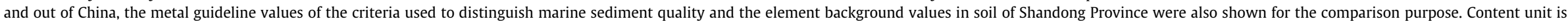
$\mu \mathrm{g} \mathrm{g}^{-1}$ for all elements.

\begin{tabular}{|c|c|c|c|c|c|c|c|c|c|c|}
\hline & & As & $\mathrm{Cd}$ & $\mathrm{Cr}$ & $\mathrm{Cu}$ & $\mathrm{Hg}$ & $\mathrm{Ni}$ & $\mathrm{Pb}$ & $\mathrm{Zn}$ & References \\
\hline \multirow[t]{2}{*}{ Laizhou Bay, China } & Range & $4.65-9.65$ & $0.11-0.28$ & $25.85-42.75$ & $7.57-21.29$ & $0.022-0.054$ & $12.85-25.35$ & $9.65-17.65$ & $38.22-73.81$ & Present study \\
\hline & Mean & 7.1 & 0.19 & 32.69 & 10.99 & 0.039 & 17.38 & 13.37 & 50.63 & \\
\hline \multirow[t]{2}{*}{ Beihai coast, China } & Range & $0.68-34.1$ & $0.06-0.82$ & $\mathrm{na}^{\mathrm{a}}$ & $4.0-32.8$ & $0.014-0.22$ & na & $1.9-72.9$ & $35.0-118.4$ & Xia et al. (2008) \\
\hline & Mean & 9.1 & 0.22 & na & 12.7 & 0.07 & na & 16.6 & 69.8 & \\
\hline \multirow{2}{*}{ Bohai Bay, China } & Range & na & $0.05-0.19$ & $36.7-110$ & $7.9-46.7$ & na & $14.1-47.9$ & $18.8-39.1$ & $34.0-123$ & Gao and Li (2012) \\
\hline & Mean & na & 0.12 & 68.6 & 24 & na & 28 & 25.6 & 73 & \\
\hline \multirow{2}{*}{ Yangtze Estuary, China } & Range & na & $0.12-0.75$ & $36.9-173$ & $6.9-49.7$ & na & $17.6-48.0$ & $18.3-44.1$ & $47.6-154$ & Zhang et al. (2009) \\
\hline & Mean & na & 0.261 & 78.9 & 30.7 & na & 31.8 & 27.3 & 94.3 & \\
\hline \multirow{2}{*}{ Quanzhou Bay, China } & Range & $17.7-30.2$ & $0.28-0.89$ & $51.1-121.7$ & $24.8-119.7$ & $0.17-0.74$ & $16.1-45.7$ & $34.3-100.9$ & $105.5-241.9$ & Yu et al. (2008) \\
\hline & Mean & 21.7 & 0.59 & 82 & 71.4 & 0.4 & 33.4 & 67.7 & 179.6 & \\
\hline \multirow{2}{*}{ San Simón Bay, Spain } & Range & $2.5-17.0$ & na & $19.9-94.1$ & $0.01-19.2$ & na & $2.19-10.6$ & $29.6-1988$ & $27.4-112.6$ & Paula et al. (2007) \\
\hline & Mean & 9.0 & na & 42.46 & 6.53 & na & 5.45 & 566.28 & 54.45 & \\
\hline California Bight, USA & & 5.1 & 0.33 & 39 & 15 & 0.05 & na & 10.9 & 59 & Schiff and Weisberg (1999) \\
\hline Class I upper limit ${ }^{\mathrm{b}}$ & & 20 & 0.5 & 80 & 35 & 0.2 & na & 60 & 150 & SEPA (2002) \\
\hline Class II upper limit ${ }^{\mathrm{C}}$ & & 65 & 1.5 & 150 & 100 & 0.5 & na & 130 & 350 & SEPA (2002) \\
\hline Class III upper limit ${ }^{\mathrm{d}}$ & & 93 & 5 & 270 & 200 & 1 & na & 250 & 600 & SEPA (2002) \\
\hline TEL guideline $\mathrm{e}^{\mathrm{e}}$ & & 7.3 & 0.68 & 52.3 & 18.7 & 0.13 & 15.9 & 30.2 & 124 & MacDonald et al. (1996) \\
\hline PEL guideline $^{\mathrm{f}}$ & & 41.6 & 4.2 & 160 & 108 & 0.7 & 42.8 & 112 & 271 & MacDonald et al. (1996) \\
\hline Background value in soil of the Shandong Province & & 9.3 & 0.084 & 66.0 & 24.0 & 0.019 & 25.8 & 25.8 & 63.5 & CNEMC (1990) \\
\hline
\end{tabular}

a na: not available.

b Class I upper limit: a marine area where sediment with metal concentrations lower than these guidelines is suitable for mariculture, nature reserve, endangered species reserve, and leisure activities such as swimming.

c Class II upper limit: a marine area where sediment with metal concentrations lower than these guidelines is suitable for industry and tourism sites.

Class III upper limit: a marine area where sediment with metal concentrations lower than these guidelines is suitable for harbors.

TEL guideline: metal concentrations in marine sediments below which adverse effects on biota are rarely observed.

PEL guideline: metal concentrations in marine sediments above which adverse effects on biota are frequently observed. 

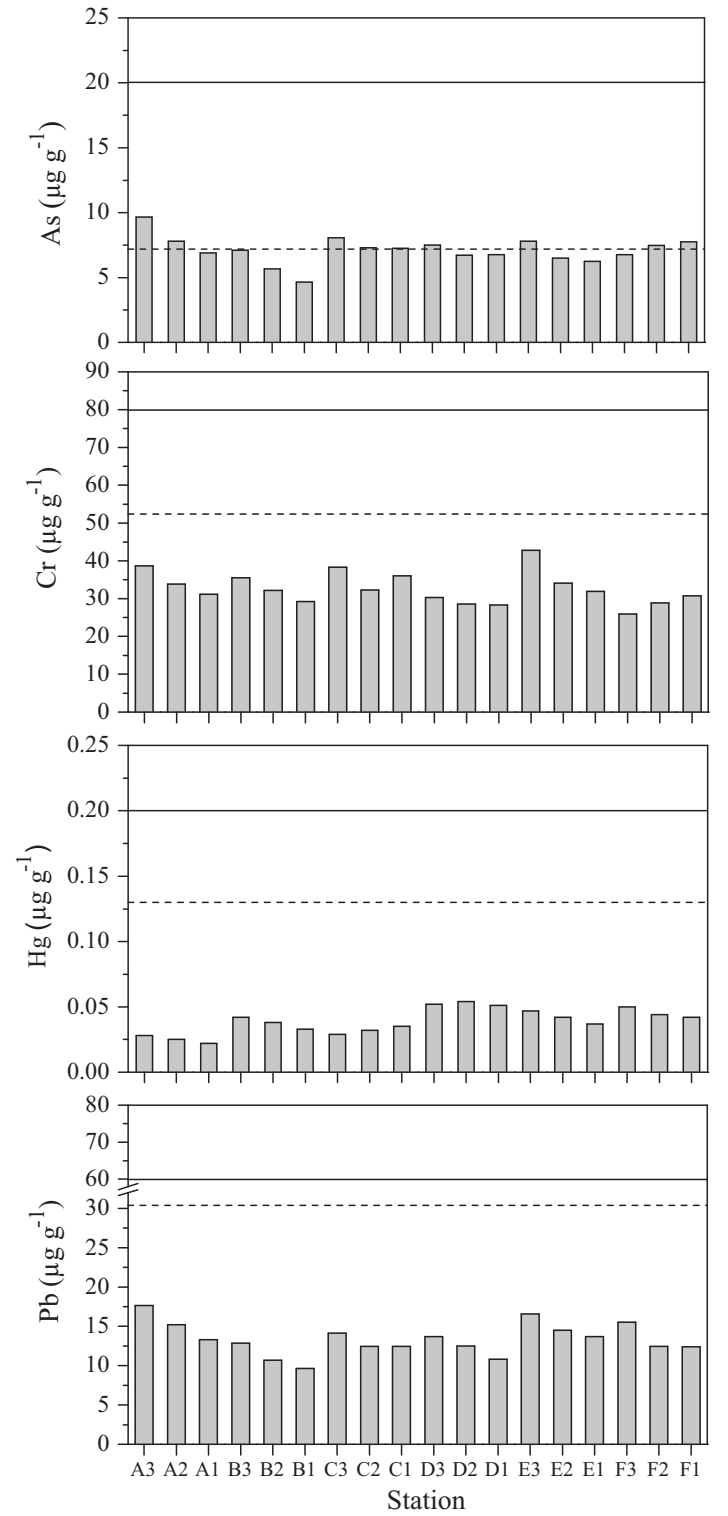
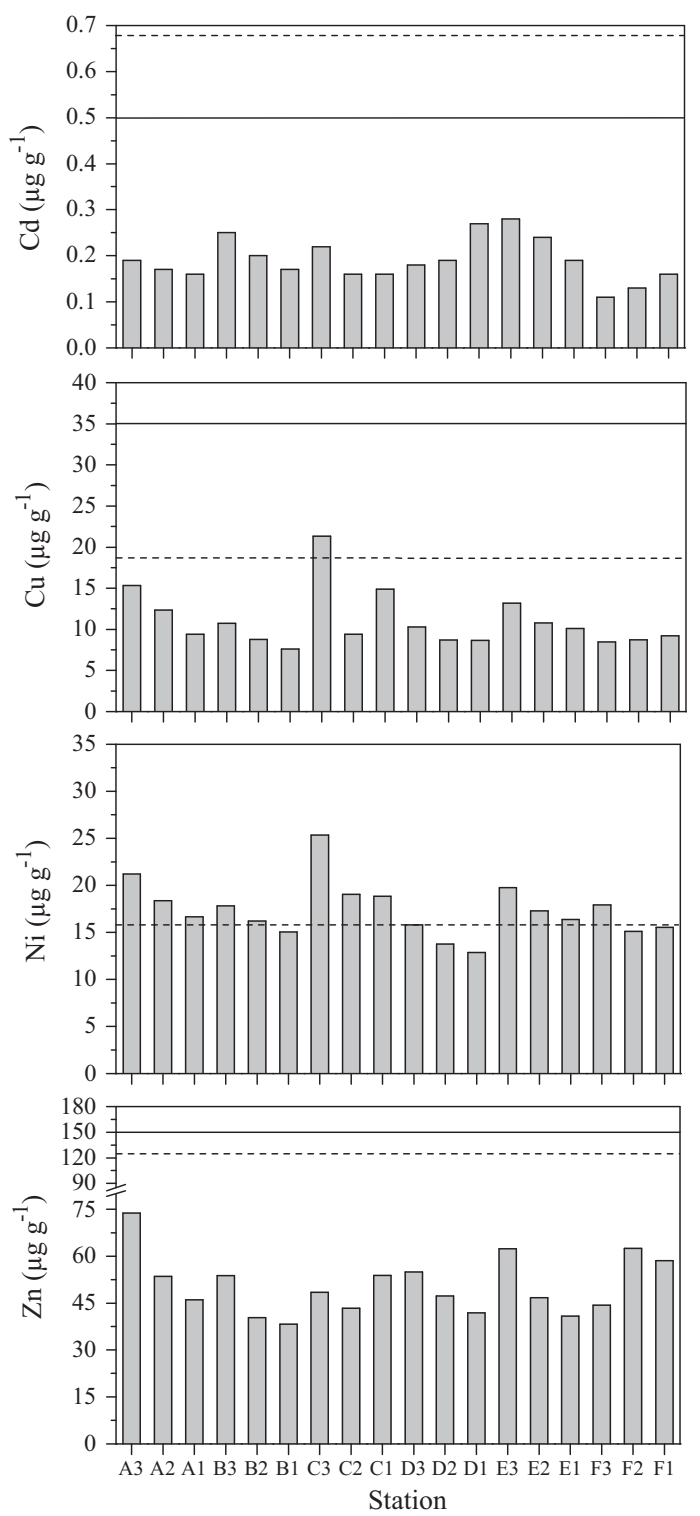

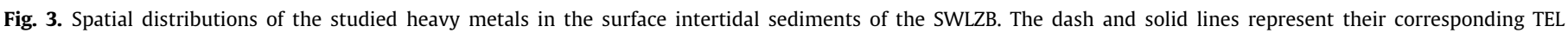
concentrations and the higher boundary values of the Class I sediment category of China, respectively.

of its clay $(<4 \mu \mathrm{m})$, silt $(4-63 \mu \mathrm{m})$ and sand $(>63 \mu \mathrm{m})$ fractions. The TOC in sediments was obtained by determining the total carbon with an Elementar vario MACRO cube CHNS analyzer after the inorganic carbon was removed with $1 \mathrm{M} \mathrm{HCl}$.

The quality assurance and quality control were done by method blanks and standard reference materials. Blank samples were also performed throughout all the analyses. To explicitly guarantee the analytical precision, all samples were determined in triplicate. Precision, expressed as relative standard deviation, was better than $10 \%$. Accuracy of the total analysis and analytical quality was assured using the standard reference materials GBW-07333 and GBW-07314. The recoveries ranged from $90 \%$ to $110 \%$ and the differences were all within $8 \%$.

In the intertidal surface sediments of the SWLZB, the clay, silt and sand fractions ranged from $2.8 \%$ to $12.5 \%, 14.4 \%$ to $61.2 \%$ and $28.5 \%$ to $82.4 \%$, with an average of $7.2 \%, 40.4 \%$ and $52.4 \%$, respectively. Therefore, the sediments in this area were mainly composed of slit and sand (Fig. 2), which was consistent with the other researchers' results in the southwestern coastal areas of the Laizhou Bay (Qiao et al., 2010; Hu et al., 2011; Zhuang and Gao,
2013). In this research, the sediments from the high tide mark were generally finer than those from the lower tide mark except for those at the C-transect and the F-transect (Fig. 2). The previously reported spatial variation pattern of surface sediment texture in the southwestern coastal areas of the Laizhou Bay (Zhuang and Gao, 2013) indicated a similar feature to this.

The TOC contents in the sediments varied from $0.09 \%$ to $0.20 \%$ with an average of $0.13 \%$ (Fig. 2). Although the TOC contents fluctuated among the sediment samples with no regular distribution patterns (Fig. 2), all of them displayed a typical concentration gradient similar to the distribution of the clay content. Generally, the concentrations of TOC were higher in the western part of the sampling areas. The TOC contents were the lowest at the non-estuary stations (D-transect; Fig. 2), indicating that the input from the rivers was an important source of TOC in the surface sediments of the studied area.

As shown in Table 1, the concentrations of As, $\mathrm{Cd}, \mathrm{Cr}, \mathrm{Cu}, \mathrm{Hg}, \mathrm{Ni}$, $\mathrm{Pb}$ and $\mathrm{Zn}$ in the surface sediments of intertidal SWLZB were in the ranges of $4.65-9.65,0.11-0.28,25.85-42.75,7.57-21.29,0.022-$ $0.054,12.85-25.35,9.65-17.65$ and $38.22-73.81 \mu \mathrm{g} \mathrm{g}^{-1}$, with the 
Table 2

Pearson correlation matrix for the sediment components.

\begin{tabular}{|c|c|c|c|c|c|c|c|c|c|c|c|c|}
\hline & As & $\mathrm{Cd}$ & $\mathrm{Cr}$ & $\mathrm{Cu}$ & $\mathrm{Hg}$ & $\mathrm{Ni}$ & $\mathrm{Pb}$ & $\mathrm{Zn}$ & \%Clay & \%Silt & \%Sand & \%TOC \\
\hline As & 1.000 & 0.039 & $0.523^{c}$ & $0.606^{\mathrm{b}}$ & -0.172 & $0.557^{c}$ & $0.727^{\mathrm{a}}$ & $0.840^{\mathrm{a}}$ & 0.386 & 0.288 & -0.366 & $0.519^{c}$ \\
\hline $\mathrm{Cd}$ & & 1.000 & $0.538^{c}$ & 0.261 & 0.203 & 0.097 & 0.067 & 0.091 & 0.317 & $0.494^{\mathrm{C}}$ & $-0.503^{\mathrm{c}}$ & $0.536^{\mathrm{c}}$ \\
\hline $\mathrm{Cr}$ & & & 1.000 & $0.757^{a}$ & -0.358 & $0.737^{\mathrm{a}}$ & $0.542^{\mathrm{c}}$ & $0.514^{c}$ & $0.764^{\mathrm{a}}$ & 0.249 & -0.379 & $0.733^{\mathrm{a}}$ \\
\hline $\mathrm{Cu}$ & & & & 1.000 & -0.399 & $0.885^{a}$ & $0.495^{\mathrm{c}}$ & $0.595^{\mathrm{c}}$ & $0.524^{c}$ & -0.033 & -0.074 & $0.435^{c}$ \\
\hline $\mathrm{Hg}$ & & & & & 1.000 & $-0.512^{\mathrm{c}}$ & -0.121 & -0.031 & $0.485^{c}$ & 0.304 & -0.169 & $0.417^{c}$ \\
\hline $\mathrm{Ni}$ & & & & & & 1.000 & $0.592^{\mathrm{b}}$ & 0.326 & $0.513^{c}$ & -0.214 & 0.085 & 0.355 \\
\hline $\mathrm{Pb}$ & & & & & & & 1.000 & $0.625^{\mathrm{b}}$ & $0.589^{c}$ & 0.435 & $-0.506^{\mathrm{c}}$ & $0.623^{c}$ \\
\hline $\mathrm{Zn}$ & & & & & & & & 1.000 & 0.324 & 0.362 & -0.389 & $0.762^{\mathrm{b}}$ \\
\hline
\end{tabular}

a $P<0.001$.
b $0.001<P<0.01$.
c $0.01<P<0.05$.

averages of $7.10,0.19,32.69,10.99,0.039,17.38,13.37$ and $50.63 \mu \mathrm{g} \mathrm{g}^{-1}$, respectively, all of which were lower than their corresponding upper limits of Class I sediment category according to the marine sediment quality classification in the National Standard of China GB18668-2002 (Table 1; SEPA, 2002), indicating that the whole studied area is suitable for mariculture, nature reserves, endangered species reserves and leisure activities in view of sediment quality. Except for $\mathrm{As}, \mathrm{Cu}$ and $\mathrm{Ni}$, the concentrations of the other studied metals, namely $\mathrm{Cd}, \mathrm{Cr}, \mathrm{Hg}, \mathrm{Pb}$ and $\mathrm{Zn}$, at all the sampling stations were below their corresponding values of threshold effects level (TEL) (Table 1; Fig. 3), which indicated that they were in a relatively uncontaminated state and might pose limited risks of toxicity.The spatial patterns of the studied heavy metals were generally similar to TOC and clay (Figs. 2 and 3). They generally showed a decreasing trend in the seaward direction except at the F-transect. Unlike those at the other transects, the metal concentrations of the sediments from the F-transect showed an increasing trend in the seaward direction, especially for As, Cd, $\mathrm{Cr}, \mathrm{Hg}$ and $\mathrm{Zn}$. Among the studied heavy metals, As and $\mathrm{Pb}$ showed less variability than the others. The maximum concentrations of $\mathrm{Cu}$ and $\mathrm{Ni}$, which were apparently higher than their corresponding values at the rest of sampling stations, were found in a sample from the high tide mark station at C-transect (Fig. 3).

Among the intertidal areas in China that were listed in Table 1, except for the mean concentration of Cd in the present study which was higher than that found in the intertidal Bohai Bay, the mean concentrations of the other seven studied metals for the intertidal sediments from the SWLZB were the lowest, while the highest values for the eight studied metals were found in sediments of the intertidal Quanzhou Bay. The average concentrations of $\mathrm{Pb}$ and As were higher than those found in sediments of the intertidal California Bight in USA, and the mean $\mathrm{Cu}$ and $\mathrm{Ni}$ concentrations were higher than those found in sediments from the intertidal San Simón Bay in Spain (Table 1). The average concentrations of $\mathrm{As}, \mathrm{Cd}, \mathrm{Cu}, \mathrm{Hg}, \mathrm{Pb}$ and $\mathrm{Zn}$ recorded in this study were comparable to those in the intertidal Beihai coast, and lower than those in the intertidal Bohai Bay, intertidal Yangtze Estuary and intertidal Quanzhou Bay (Table 1).

The correlation matrix for the parameters studied was shown in Table 2. Except the relationships between Cd and the other metals and between $\mathrm{Hg}$ and the other metals, generally most of the studied metals were significantly correlated with each other, suggesting a major common origin for sediments. The special conditions of $\mathrm{Cd}$ and $\mathrm{Hg}$ in the sediments indicated they probably had different origins from the other studied metals. Except for As, Cd and Zn, the concentrations of other studied heavy metals and the clay contents were significantly correlated with each other, and except for $\mathrm{Ni}$, the concentrations of other studied heavy metals and TOC contents were significantly correlated with each other too. These findings were similar to the previous study by Gao and Chen (2012), the results of which indicated that the concentrations of $\mathrm{Cd}$ and
$\mathrm{Zn}$ appeared to be more influenced by the amount of organic matter than by the sediment grain size composition and the concentration of $\mathrm{Ni}$ appeared to be more influenced by the sediment grain size composition than by the amount of organic matter.

The distribution of heavy metals in sediments was related to the deposition and transportation processes from sources to sinks in the intertidal zone. The heavy metals and their transportation in the intertidal sediments could be influenced by physical, chemical and biological processes of the intertidal system. Through these processes heavy metals deposited and incorporated into sediments.

The grain size and sediment components can affect the concentrations of heavy metals in the intertidal area, since the increasing specific surface of fine sediments favored adsorption processes. Correlation analysis indicated that the heavy metals and the clay contents were significantly correlated with each other (Table 2). Such a phenomenon suggested that the fine particles contained more heavy metals and might be a major carrier of them. Accordingly, the distribution of fine-grained sediment could reflect the physical transportation of heavy metals in the sediments. In this research, corresponding to the clay distribution, metal concentrations of the sediments from the high tide mark were generally higher than the sediments from the low tide mark (Fig. 3).

The transportation and deposition of heavy metals were controlled by material sources, transportation media, transportation modes and the sedimentary environment. The sediment transportation and distribution were strongly affected by hydrodynamic processes and the deposition conditions. As mentioned above, in the intertidal zone of the SWLZB, the sediments from the high tide mark were finer than the sediments from the low tide mark (Fig. 2). This distribution pattern could be the consequence of joint effects of tidal currents, residual currents, coastal currents, continental diluted currents, the anti-clockwise circulation of the Laizhou Bay and the sudden change in the velocity of water currents. These hydrodynamic processes caused the re-suspension of fine surface sediments near the estuaries in the Bohai Sea (Jiang et al., 2000; Qiao et al., 2010). The sediments transported into the intertidal zone of this region could be mainly from the rivers (i.e. the Xiaoqinghe River, the Bailanghe River, the Yuhe River, the Weihe River and the Jiaolaihe River). When sediments were transported from rivers into intertidal zone, the coarse grained sediments deposited quickly, while the fine parts of sediments could be more easily retained in seawaters, moved and sorted by the above-mentioned hydrodynamic processes.

Organic matter is an important component of fine-grained marine sediments, and heavy metals often deposit in sediments combining with organic matter. The TOC contents in the intertidal zone of the SWLZB surface sediments were $0.09-0.20 \%$ with an average of $0.13 \%$ (Fig. 2). The TOC contents in the high tide mark were higher than in the low tide mark (Fig. 2). This research found that concentrations of most studied heavy metals and TOC 
contents had significant correlations except for Ni (Table 2), indicating that these metals and organic matter may have common origin and were probably introduced to the system with organic matters. The dead phytoplankton, byproduct of the zooplankton, benthos metabolic activities and bacterial degradation would accelerate the organic matter accumulation and release (Dellwig et al., 2007). So, the organism biomass and the associated growth of bacteria were the controlling factors of the organic matter and coupled metals.

An essential task of geochemical research is to distinguish elements originating from anthropogenic activities and those from natural crustal contribution. Normalization is a widely applied technique, that is metal concentrations are normalized to a textural or compositional characteristic of sediments. Al is a commonly used normalizing element to compensate for fluctuations in both grain size and composition, since it represents the quantity of aluminosilicates, which is the predominant carrier phase for adsorbed elements in coastal sediments (Chatterjee et al., 2007). This method is also an effective tool for the regional comparison of trace metal concentration in sediments and can also be applied to determine enrichment factors (EFs). It is defined as the concentration ratio of a considered element to a reference element in a given sample, divided by the same ratio of their background concentrations, that is:

$$
\mathrm{EF}=\frac{\left(C_{\mathrm{x}} / C_{\mathrm{Al}}\right)_{\text {Sample }}}{\left(C_{\mathrm{x}} / C_{\mathrm{Al}}\right)_{\text {Background }}}
$$

where $C_{\mathrm{x}}$ and $C_{\mathrm{Al}}$ denote the concentrations of elements " $\mathrm{x}$ " and $\mathrm{Al}$ in the samples of interest (Sample) and their background concentrations (Background) (Table 1). According to the recently published literature of Xu et al. (2015), sediment in the Laizhou Bay was primarily from the material discharged by rivers along its western and southern coasts. So, the element background concentrations in soil of Shandong Province were adopted to calculate the EF values in this research as that of Xu et al. (2015) did. It is generally accepted that it may be entirely from crustal materials or natural weathering processes if the EF value of a metal in solid geochemical samples such as marine sediments or suspended particulate matter is between 0.5 and 1.5, and a significant portion of it is from other sources rather than natural origins if its $\mathrm{EF}$ value is greater than 1.5 (Zhang and Liu, 2002; Feng et al., 2004).

In order to get information about the potential sources of heavy metals in the intertidal sediments of the SWLZB, the EF value of each element at each station was calculated. The results showed that the EF values of the eight studied heavy metals followed the sequence $\mathrm{Cd}>\mathrm{Hg}>\mathrm{Zn}>\mathrm{As}>\mathrm{Ni}>\mathrm{Pb}>\mathrm{Cr}>\mathrm{Cu}$ (Fig. 4). The mean

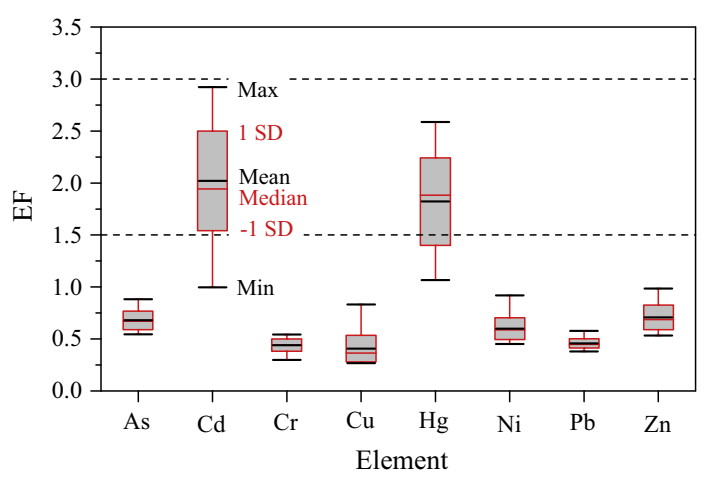

Fig. 4. Enrichment factors of the studied heavy metals in the surface sediments in intertidal SWLZB using $\mathrm{Al}$ as normalizer. Values in the section below the bottom dot line $(\mathrm{EF}<1.5)$ suggest that the elements may be entirely from crustal materials or natural weathering processes; values in the section between the two dot lines $(1.5<\mathrm{EF}<3)$ indicates that a portion of the elements may be from other sources rather than natural origins.
EF values of $\mathrm{Cd}$ and $\mathrm{Hg}$ were higher than 1.5 , while those of the other studied metals fell in the range of natural variability. Therefore, $\mathrm{Cd}$ and $\mathrm{Hg}$ were the most anthropogenically influenced among the studied elements in the surface sediments of the intertidal SWLZB based on the results of EF analysis. With a mean value of 2.02, the EF values of Cd varied greatly across the studied area, and they were over 1.5 but less than 3 at all stations except stations F3 and F2, indicating a minor enrichment status. The EF values of $\mathrm{Hg}$ at all sampling stations were over 1 with a mean value of 1.82 , and 14 of them exceeding 1.5 but less than 3 , suggesting a minor enrichment status too. Except for $\mathrm{Cd}$ and $\mathrm{Hg}$, the EF values of the other studied metals were lower than 1, suggesting that they were not enriched and might be mainly from the Earth's crust. Except for $\mathrm{Hg}$, the EF values of the metals at the western sampling stations were generally higher than those at the eastern stations, indicating that the western sampling area was relatively more enriched by heavy metals than the eastern area. The spatial distribution pattern of $\mathrm{EF}_{\mathrm{Hg}}$ suggested that the major sources of $\mathrm{Hg}$ in the sampling area might be different from that of the other studied metals; such a case was reassured by Pearson correlation analyses (Table 2), and $\mathrm{Hg}$ presented insignificant correlations with the other metals which differentiates it from the other seven metals. Generally speaking, the heavy metal pollution in the intertidal sediments of the SWLZB was not serious based on the results of EF analysis.

The $I_{\text {geo }}$ was used to evaluate the levels of heavy metal contamination and possible sediment enrichment of metals. The formula used for the calculation of $I_{\text {geo }}$ is:

$I_{\text {geo }}=\log _{2}\left(\frac{C_{\mathrm{x}}}{1.5 B_{\mathrm{x}}}\right)$

where $C_{\mathrm{x}}$ is the measured concentration of element " $\mathrm{x}$ ", and $B_{\mathrm{x}}$ is the geochemical background concentration of element " $x$ ". As in the EF calculation, the corresponding metal background concentration in soil of Shandong Province (Table 1) was adopted as $B_{\mathrm{x}}$. The calculated $I_{\text {geo }}$ values of the studied metals are shown in Fig. 5. The $I_{\text {geo }}$ values of six studied metals ( $\mathrm{As}, \mathrm{Cr}, \mathrm{Cu}, \mathrm{Ni}, \mathrm{Pb}$ and $\mathrm{Zn}$ ) at all sampling stations were less than 1 , suggesting that they were in an unpolluted status in the intertidal surface sediments of the SWLZB. Exactly like the descending order of the studied metals on EF values, the mean value of 0.56 meant that $\mathrm{Cd}$ was relatively the most contaminated metal of all based on the results of $I_{\text {geo }}$ analysis, followed by $\mathrm{Hg}, \mathrm{Zn}, \mathrm{As}, \mathrm{Ni}, \mathrm{Pb}, \mathrm{Cd}$ and $\mathrm{Cu}$ in sequence, the mean values of which were $0.41,-0.93,-0.99,-1.17,-1.55,-1.61$ and -1.76 , respectively. According to Müller (1969), metals in the surface sediments of this study could be classified into the following

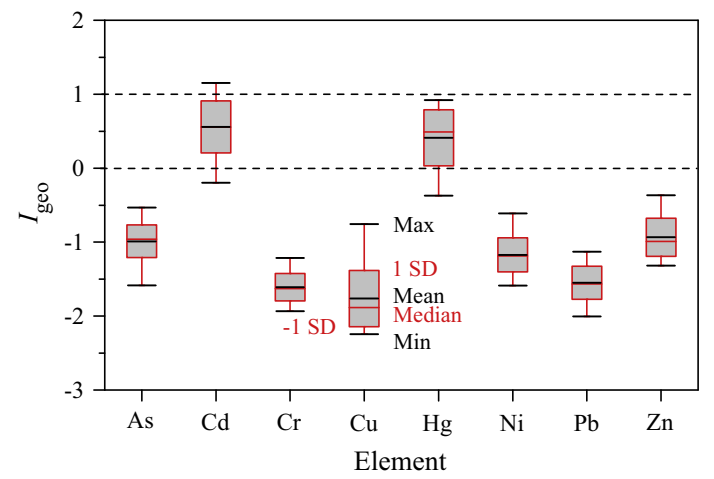

Fig. 5. Index of geoaccumulation of the studied heavy metals in the surface sediments in the intertidal SWLZB. Values in the section below the bottom dot line $\left(I_{\text {geo }}<0\right)$ indicate that the elements were at a practically unpolluted level; values in the section between the two dot lines $\left(0 \leqslant I_{\text {geo }}<1\right)$ indicate that the elements were at an unpolluted to moderately polluted level; values in the section above the top dot line $\left(1 \leqslant I_{\text {geo }}<2\right)$ indicate that the elements were at a moderately polluted level. 
two groups based on the pollution potential: (1) practically unpolluted $\left(I_{\text {geo }}<0\right)$, which was the case of $\mathrm{As}, \mathrm{Cr}, \mathrm{Cu}, \mathrm{Ni}, \mathrm{Pb}$ and $\mathrm{Zn}$; (2) unpolluted to moderately polluted $\left(0<I_{\text {geo }}<1\right)$, which was the case of $\mathrm{Cd}$ and $\mathrm{Hg}$. The general information that the $I_{\text {geo }}$ results of $\mathrm{Cd}, \mathrm{Cr}$, $\mathrm{Cu}, \mathrm{Ni}, \mathrm{Pb}$ and $\mathrm{Zn}$ indicated in this study was similar to the previous observation on the surface sediments in the inshore area of the SWLZB reported by Gao et al. (2015b).

The EF and $I_{\text {geo }}$ were techniques through which individual metals are assessed by normalization. But the fact is that heavy metals always occur in sediments as complex mixtures, and they form combined toxicant groups in sediments. In order to evaluate the possible biological effects of the coupled toxicity of the studied metals in the surface intertidal sediments of the SWLZB, the mean PEL quotient method introduced by Carr et al. (1996) was used and values were calculated using the following formula:

mean PEL quotient $=\frac{\sum_{x=1}^{n} \frac{C_{x}}{P E L_{x}}}{n}$

where $C_{\mathrm{x}}$ is the sediment concentration of metal " $\mathrm{x}$ ", $P E L_{\mathrm{x}}$ is the PEL (probable effects level; Table 1 ) for metal " $x$ ", " $n$ " is the number of the studied metals and is 8 in this study. It was reported that the mean PEL quotients of $<0.1$ have a $9 \%$ probability of being toxic, the mean PEL quotients of $0.11-0.5$ have a $21 \%$ probability of being toxic, the mean PEL quotients of $0.51-1.5$ have a $49 \%$ probability of being toxic, and the mean PEL quotients of $>1.50$ have a $76 \%$ probability of being toxic (Long et al., 2000). It can be seen in Fig. 6 that the mean PEL quotients in the surface intertidal sediments of the SWLZB varied within the range of $0.13-0.20$, indicating that the

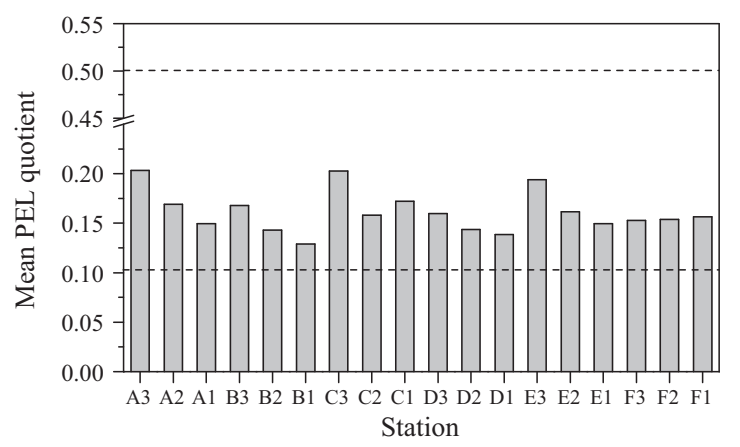

Fig. 6. The mean PEL quotients of the studied metals in each sampling station. Values in the section between the two dot lines $(0.11<$ mean PEL quotient $<0.5)$ indicate that the combined effect of the studied metals in the sediments has a $21 \%$ probability of toxicity to biota. combined effects of the studied metals in the sediments may cause a $21 \%$ probability of being toxic to biota.

For the purpose of evaluating the potential risk to the intertidal ecosystem posed by the heavy metals in the intertidal surface sediments of the SWLZB, ecological risk assessment was conducted in this research. The ecological risk index (RI), which was originally introduced by Håkanson (1980), was calculated as:

$E_{r}^{i}=T_{r}^{i} \cdot C_{f}^{i}=T_{r}^{i} \cdot\left(C_{o}^{i} / C_{n}^{i}\right)$

$\mathrm{RI}=\sum_{i=1}^{8} E_{r}^{i}=\sum_{i=1}^{8} T_{r}^{i} \cdot C_{f}^{i}$

where $E_{r}^{i}$ is the potential ecological risk factor of metal "i"; $T_{r}^{i}$ and $C_{f}^{i}$ are the toxic-response factor and the contamination factor of metal "i", respectively; $C_{0}^{\mathrm{i}}$ and $C_{n}^{i}$ are the measured concentrations of metal "i" in the sample and its reference value, respectively. The $T_{r}^{i}$ values of $\mathrm{As}, \mathrm{Cd}, \mathrm{Cr}, \mathrm{Cu}, \mathrm{Hg}, \mathrm{Ni}, \mathrm{Pb}$ and $\mathrm{Zn}$ are 10, 30, 2, 5, 40, 5, 5 and 1, respectively (Håkanson, 1980; Wang et al., 2011). RI indicates the total potential ecological risk for a sampling region based on the sensitivity of the ecosystem to all the studied heavy metals. Like that of EF and $I_{\text {geo }}$ calculation, the corresponding metal background concentrations in soil of Shandong Province (Table 1) were adopted to calculate the $E_{r}^{i}$ and RI values of the studied metals in this study. According to Håkanson (1980), the potential ecological risk of heavy metals in sediments can be divided into the following categories: Low risk: $E_{r}^{i}<40, \mathrm{RI}<150$; Moderate risk: $40 \leqslant E_{r}^{i}<80$, $150 \leqslant \mathrm{RI}<300$; Considerable risk: $80 \leqslant E_{r}^{i}<160,300 \leqslant \mathrm{RI}<600$; High risk: $160 \leqslant E_{r}^{i}<320$; Very high risk: $E_{r}^{i} \geqslant 320, \mathrm{RI} \geqslant 600$.

Fig. 7 shows the calculated $E_{r}^{i}$ values of each metal and RI of the eight studied metals in the intertidal surface sediments from the SWLZB. Overall, the ecological risk of studied metals in the intertidal surface sediments of the SWLZB was from low to considerable, and the risks were mainly from $\mathrm{Cd}$ and $\mathrm{Hg}$. It can be seen that $\mathrm{Hg}$ presented the highest ecological risk among the eight heavy metals, primarily due to its high toxic-response factor. $E_{r}^{i}$ of Hg fluctuated greatly across the studied area compared to the other studied metals, with the range from 46.3 to 113.7 and a mean value of 82.2 which exceeded 80 , indicating on the whole a considerable risk from $\mathrm{Hg}$. $E_{r}^{i}$ values of Cd ranged from 39.3 to 100 , and its mean $E_{r}^{i}$ value was 68.1 , indicating that it had a moderate risk in general. $E_{r}^{i}$ values of the other six studied elements, namely As, $\mathrm{Ni}, \mathrm{Cu}, \mathrm{Pb}, \mathrm{Cr}$ and $\mathrm{Zn}$, were all far below 40 , indicating a low ecological risk from them. The RI values indicated that they were higher than 150 at 13 of the sampling stations showing that the surface sediments at these sampling stations were generally at a moderate
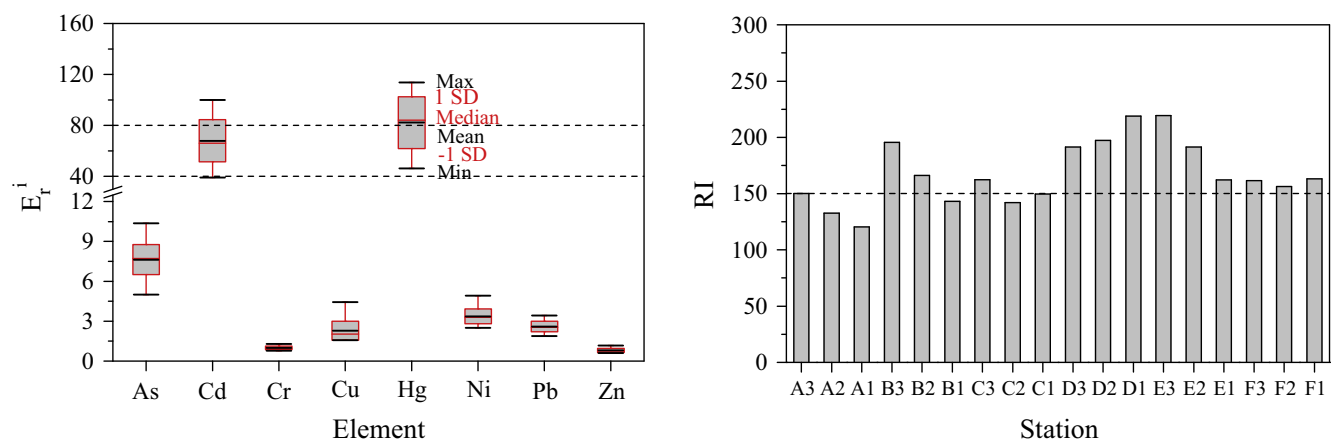

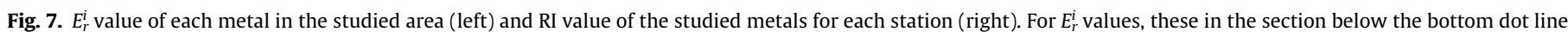

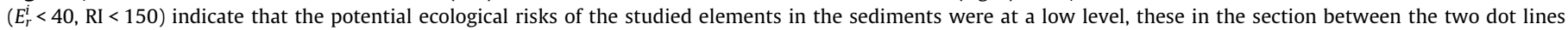

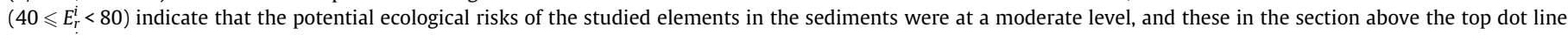

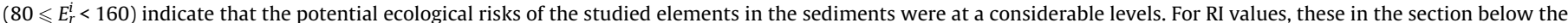

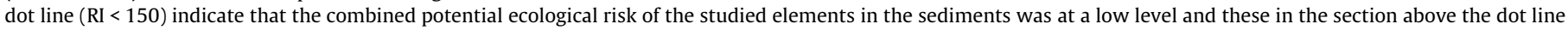
$(150 \leqslant \mathrm{RI}<300)$ indicate that the combined potential ecological risk of the studied elements in the sediments was at a moderate level. 
ecological risk level in terms of the combined effects of the studied heavy metals, while they were lower than 150 at stations A2, A1, B1, C2 and C1 showing that the combined effects of the studied heavy metals had a low ecological risk for the environment (Fig. 7).

\section{Acknowledgments}

The authors are grateful to all the group members for their constant field and laboratory assistance, helpful advice and in-depth discussion. This study was co-supported by the National Natural Science Foundation of China (41376083) and the Department of Science and Technology of Shandong Province (2012GHY11535).

\section{References}

Besser, J., Brumbaugh, W., Allert, A., Poulton, B., Schmitt, C., Ingersoll, C., 2009. Ecological impacts of lead mining on Ozark streams: toxicity of sediment and pore water. Ecotoxicol. Environ. Safety 72, 516-526.

Breslin, V.T., Sañudo-Wilhelmy, S.A., 1999. High spatial resolution sampling of metals in the sediment and water column in Port Jefferson Harbor, New York. Estuaries 22, 669-680.

Carr, R.S., Long, E.R., Windom, H.L., Chapman, D.C., Thursby, G., Wolfe, D.A., Sloane G.M., 1996. Sediment quality assessment studies of Tampa Bay, Florida. Environ. Toxicol. Chem. 15, 1218-1231.

Chapman, P.M., Wang, F., Janssen, C., Persoone, G., Allen, H.E., 1998. Ecotoxicology of metals in aquatic sediments binding and release, bioavailability, risk assessment, and remediation. Can. J. Fish. Aquat. Sci. 55, 2221-2243.

Chatterjee, M., Silva, E.V., Sarkar, S.K., Sella, S.M., Bhattacharya, A., Satpathy, K.K., Prasad, M.V.R., Chakraborty, S., Bhattacharya, B.D., 2007. Distribution and possible source of trace elements in the sediment cores of a tropical macrotidal estuary and their ecotoxicological significance. Environ. Int. 33, 346-356.

CNEMC (China National Environmental Monitoring Center), 1990. Chinese elemental background values for soils. Chinese Environmental Science Press, Beijing.

Dellwig, O., Lemke, M.A., Lunau, M., Kolditz, K., Schnetger, B., Brumsack, H.J., 2007. Non-conservative behaviour of molybdenum in coastal waters. Geochim. Cosmochim. Acta 71, 2745-2761.

Ding, Z., Liu, J., Li, L., Lin, H., Wu, H., Hu, Z., 2009. Distribution and speciation of mercury in surficial sediments from main mangrove wetlands in China. Mar. Pollut. Bull. 58, 1319-1325.

Dural, M., Göksu, M.Z.L., Özak, A.A., 2007. Investigation of heavy metal levels in economically important fish species captured from the Tuzla lagoon. Food Chem. 102, 415-421.

Duran, R., Ranchou, P.M., Menuet, V., Monperrus, M., Bareille, G., Goňi, M., Salvado, J., Amouroux, D., Guyoneaud, R., Donard, O., Caumette, P., 2008. Mercury methylation by a microbial community from sediments of the Adour Estuary (Bay of Biscay, France). Environ. Pollut. 156, 951-958.

Feng, H., Han, X., Zhang, W., Yu, L., 2004. A preliminary study of heavy metal contamination in Yangtze River intertidal zone due to urbanization. Mar. Pollut. Bull. 49, 910-915.

Feng, H., Jiang, H.Y., Gao, W.S., Weinstein, M.P., Zhang, Q.F., Zhang, W.G., Yu, L.Z., Yuan, D.K., Tao, J.H., 2011. Metal contamination in sediments of the western Bohai Bay and adjacent estuaries, China. J. Environ. Manage. 92, 1185-1197.

Gao, X.L., Chen, C.T.A., 2012. Heavy metal pollution status in surface sediments of the coastal Bohai Bay. Water Res. 46 (6), 1901-1911.

Gao, X.L., Li, P.M., 2012. Concentration and fractionation of trace metals in surface sediments of intertidal Bohai Bay, China. Mar. Pollut. Bull. 64, 1529-1536.

Gao, X.L., Li, P.M., Chen, C.T.A., 2013. Assessment of sediment quality in two important areas of mariculture in the Bohai Sea and the northern Yellow Sea based on acid-volatile sulfide and simultaneously extracted metal results. Mar. Pollut. Bull. 72, 281-288.

Gao, X.L., Zhou, F.X., Chen, C.T.A., 2014. Pollution status of the Bohai Sea, China: an overview of the environmental quality assessment related trace metals. Environ. Int. 62, 12-30.

Gao, X.L., Zhou, F.X., Chen, C.T.A., 2015a. Trace metals in the suspended particulate matter of the Yellow River (Huanghe) Estuary: concentrations, potential mobility, contamination assessment and the fluxes into the Bohai Sea. Cont. Shelf Res. 104, 25-36.

Gao, X.L., Zhuang, W., Chen, C.T.A., Zhang, Y., 2015b. Sediment quality of the SW coastal Laizhou Bay, Bohai Sea, China: a comprehensive assessment based on the analysis of heavy metals. PLOS ONE 10 (3), e0122190. http://dx.doi.org/ 10.1371 /journal.pone.0122190.

Håkanson, L., 1980. An ecological risk index for aquatic pollution control: a sedimentological approach. Water Res. 14, 975-1001.

Hu, N.J., Shi, X.F., Liu, J.H., Huang, P., Yang, G., Liu, Y.G., 2011. Distributions and impacts of heavy metals in the surface sediments of the Laizhou Bay. Adv. Mar. Sci. 29, 63-72 (in Chinese).
Jiang, W.S., Pohlmann, T., Sudermann, J., Feng, S.Z., 2000. A modeling study of SPM transport in the Bohai Sea. J. Mar. Syst. 24, 175-200.

Lau, S.S., Chu, L.M., 2000. The significance of sediment contamination in a coastal wetland, Hong Kong, China. Water Res. 34, 379-386.

Li, P.M., Gao, X.L., 2014. Trace elements in major marketed marine bivalves from six northern coastal cities of China: concentrations and risk assessment for human health. Ecotoxicol. Environ. Safety 109, 1-9.

Li, L., Wang, X., Zhu, A., Yang, G., Liu, J., 2014. Assessing metal toxicity in sediments of Yellow River wetland and its surrounding coastal areas, China. Estuar. Coast. Shelf Sci. 151, 302-309.

Long, E.R., MacDonald, D.D., Smith, S.C., Calder, F.D., 1995. Incidence of adverse biological effects within ranges of chemical concentrations in marine and estuarine sediments. Environ. Manage. 19, 81-97.

Long, E.R., MacDonald, D.D., Severn, C.G., Hong, C.B., 2000. Classifying the probabilities of acute toxicity in marine sediments with empirically-derived sediment quality guidelines. Environ. Toxicol. Chem. 19, 2598-2601.

MacDonald, D.D., Scottcarr, R., Calder, F.D., Long, E.R., Ingersoll, C.G., 1996. Development and evaluation of sediment quality guidelines for Florida coastal waters. Ecotoxicology 5, 253-278.

Müller, G., 1969. Index of geoaccumulation in the sediments of the Rhine River. Geojournal 2, 108-118.

Pan, K., Wang, W.X., 2011. Trace metal contamination in estuarine and coastal environments in China. Sci. Total Environ. 421-422, 3-16.

Paula, A.I., Begona, Q., Belen, R., Marta, P.A., 2007. Sedimentation rates and trace metal input history in intertidal sediments from San Simón Bay derived from 210Pb and 137Cs chronology. J. Environ. Radioactiv. 98, 229-250.

Qiao, S.Q., Shi, X.F., Zhu, A.M., Liu, Y.G., Bi, N.S., Fang, X.S., Yang, G., 2010. Distribution and transport of suspended sediments off the Yellow River (Huanghe) mouth and the nearby Bohai Sea. Estuar. Coast. Shelf Sci. 86, 337344.

Schiff, K.C., Weisberg, S.B., 1999. Iron as a reference element for determining trace metal enrichment in Southern California coastal shelf sediments. Mar. Environ. Res. 48, 161-176.

SEPA (State Environmental Protection Administration of China), 2002. Marine sediment quality GB18668-2002. Standards Press of China, Beijing.

Snodgrass, J.W., Casey, R.E., Joseph, D., Simon, J.A., 2008. Microcosm investigations of storm water pond sediment toxicity to embryonic and larval amphibians: variation in sensitivity among species. Environ. Pollut. 154, 291-297.

Spencer, K.L., 2002. Spatial variability of metals in the inter-tidal sediments of the Medway estuary, Kent, UK. Mar. Pollut. Bull. 44, 933-944.

Wang, Y., Yang, Z., Shen, Z., Tang, Z., Niu, J., Gao, F., 2011. Assessment of heavy metals in sediments from a typical catchment of the Yangtze River, China. Environ. Monit. Assess. 172, 407-417.

Wu, B., Song, J.M., Li, X.G., 2014. Evaluation of potential relationships between benthic community structure and toxic metals in Laizhou Bay. Mar. Pollut. Bull. 87, 247-256.

Xia, P., Meng, X.W. Yin, P. Liu, L.J., 2008. Heavy metal pollution and its potential ecological risk in the sediments from the Beihai Intertidal Zone of Guangxi Province. Adv. Mar. Sci. 26, 471-477 (in Chinese).

Xu, G., Liu, J., Pei, S.F., Gao, M.S., Hu, G., Kong, X.H., 2015. Sediment properties and trace metal pollution assessment in surface sediments of the Laizhou Bay, China. Environ. Sci. Pollut. Res. http://dx.doi.org/10.1007/s11356-015-4393-y.

Yu, R.L., Yuan, X., Zhao, Y.H., Hu, G.R., Tu, X.L., 2008. Heavy metal pollution in intertidal sediments from Quanzhou Bay, China. J. Environ. Sci. 20, 664-669.

Yu, Y., Song, J.M., Li, X.G., Yuan, H.M., Li, N., 2013. Fractionation, sources and budgets of potential harmful elements in surface sediments of the East China Sea. Mar. Pollut. Bull. 68 (1-2), 157-167.

Yuan, H.M., Song, J.M., Li, X.G., Li, N., Duan, L.Q., 2012. Distribution and contamination of heavy metals in surface sediments of the South Yellow Sea. Mar. Pollut. Bull. 64 (10), 2151-2159.

Zhang, J., Liu, C.L., 2002. Riverine composition and estuarine geochemistry of particulate metals in China-weathering features, anthropogenic impact and chemical fluxes. Estuar. Coast. Shelf Sci. 54, 1051-1070.

Zhang, W.G., Feng, H., Chang, J.N., Qu, J.G., Xie, H.X., Yu, L.Z., 2009. Heavy metal contamination in surface sediments of Yangtze River intertidal zone: an assessment from different indexes. Environ. Pollut. 157, 1533-1543.

Zheng, N., Wang, Q., Liang, Z., Zheng, D., 2008. Characterization of heavy metal concentrations in the sediments of three freshwater rivers in Huludao city, Northeast China. Environ. Pollut. 154, 135-142.

Zhuang, W., Gao, X.L., 2013. Acid-volatile sulfide and simultaneously extracted metals in surface sediments of the southwestern coastal Laizhou Bay, Bohai Sea: concentrations, spatial distributions and the indication of heavy metal pollution status. Mar. Pollut. Bull. 76, 128-138.

Zhuang, W., Gao, X.L., 2014a. Assessment of heavy metal impact on sediment quality of the Xiaoqinghe estuary in the coastal Laizhou Bay, Bohai Sea: Inconsistency between two commonly used criteria. Mar. Pollut. Bull. 83, 352357.

Zhuang, W., Gao, X.L., 2014b. Integrated assessment of heavy metal pollution in the surface sediments of the Laizhou Bay and the coastal waters of the Zhangzi Island, China: comparison among typical marine sediment quality indices. PLOS ONE 9 (4), e94145. http://dx.doi.org/10.1371/journal.pone.0094145. 